\title{
A Study of Lipid Peroxidation in Ischemic Stroke
}

\author{
A.K. Sood, A. Mahajan, D. Sindhu, A. Dua, S. Seth
}

\begin{abstract}
Abstrak
Telah dilakukan pengukuran malonil dialdehid serum (MDA) pada 25 kasus stroke iskemik dan 25 kelola untuk mengetahui hubungan beratnya stroke dengan hasil penanganan. Umur rerata kasus stroke adalah $53.08 \pm 15.01$ tahun, dan rasio lakiperempuan adalah 3:2. Penentuan MDA serum dilakukan dengan cara Placer dkk. MDA serum pada kasus lebih tinggi secara bermakna dibanding kelola $(3.33 \pm 0.75 \mu \mathrm{mol} / \mathrm{L}$ vs. $1.73 \pm 0.48 \mu \mathrm{mol} / \mathrm{L}, p<0.001)$. Angka ini lebih tinggi pada kasus yang pengukuran MDA nya dilakukan dalam 6 jam pertama serangan stroke. Tidak ada korelasi dengan ketiba-tibaan serangan stroke, dengan lokasi dan luasnya infark, atau dengan beratnya stroke sebagaimana ditentukan oleh Modified National Institute of Health Stroke Scale.
\end{abstract}

\begin{abstract}
Serum malonyl dialdehyde (MDA) level, an index of lipid peroxidation, was estimated in twenty five CT proved ischemic stroke subjects and 25 age and sex matched healthy controls, to find out its correlation with severity and outcome of stroke. Mean age of stroke patients was $53.08 \pm 15.01$ years and male-female ratio was 3:2. Estimation of serum MDA levels was done by the method of Placer et al. Serum MDA levels were found to be significantly high in ischemic stroke patients compared to controls $(3.33 \pm 0.75 \mu \mathrm{molL} v \mathrm{~s} .1 .73$ $\pm 0.48 \mu \mathrm{mol} / \mathrm{L}, p<0.001)$. The levels were higher in those in whom MDA levels were estimated within 6 hours of onset of stroke. MDA levels had no correlation with the suddenness of the stroke, with site and extent of infarction or with the severity and outcome of stroke as determined by Modified National Institute of Health Stroke Scale.
\end{abstract}

Keywords : Lipid peroxidation, Cerebrovascular accident, Ischemic stroke, Malonyl dialdehyde

Stroke is the third leading cause of death after ischemic heart disease and cancer in the developed countries. Although mortality rates are declining, stroke continues to be a major cause of disability. Thus discovery of means to limit the ischemic injury caused to the tissues may help in decreasing the total burden on the society. Ischemic injury to tissues, e.g. myocardial infarction and cerebral stroke, is partially mediated by abundant production of free oxygen radicals. Lipid peroxidation has been broadly defined as the oxidative deterioration of polyunsaturated fatty acids, a process responsible for the production of free radicals.

Lipid peroxidation is a process normally occuring at low levels in all cells and tissues. Although a variety of antioxidant mechanisms control lipid peroxidation, but under certain conditions the protective mechanisms can be overwhelmed, leading to elevated steady state tissue levels of peroxidative products in tissues. Conditions that can stimulate lipid peroxida-

Department of Neurology and Biochemistry, Pandit B.D. Sharma Postgraduate Institute of Medical Sciences, Haryana, India tion are numerous and include hypoxia, hyperoxia, copper and iron toxicity and antioxidant deficiencies. ${ }^{1,2}$ Imbalance between peroxidant and antioxidant forces in which the former dominates may be broadly defined as oxidative stress, of which lipid peroxidation is an important manifestation. Although lipid peroxidation affects many cellular components, the primary reaction sites involve membrane- associated polyunsaturated fatty acids and protein thiols. ${ }^{3}$ Peroxidation of membrane-associated fatty acids and cholesterol alters cell membrane fluidity and permeability characteristics and may eventually induce widespread membrane damage. ${ }^{4}$ During experimental studies, Tomita et al ${ }^{5}$ have described elevation of lipid peroxide in the blood of stroke prone spontaneously hypertensive rats shortly before the occurence of stroke. Similarly, Kibata et al ${ }^{6}$ also observed that the levels of free fatty acids and thiobarbituric acid reactive substances, indicative of lipid peroxidation, were high in the serum of patients with stroke.

Keeping the above facts in mind, it was planned to study lipid peroxidation by estimation of malonyl dialdehyde (MDA) levels, an index of lipid peroxidation, in serum of patients of ischemic stroke and to establish 
correlation, if any, between serum MDA levels and the severity of neurological deficit.

\section{MATERIALS AND METHODS}

Twenty five patients of ischemic stroke, irrespective of age and sex, admitted to our institute were included in this study. Another 25 healthy subjects matched for age $\&$ sex served as control. The study approved by the ethical committee of the hospital. The criteria laid down by $\mathrm{WHO}^{7}$ to establish the clinical diagnosis of stroke were followed and only $\mathrm{CT}$ proved cases of cerebral thrombosis were included. Patients suffering from TIA, AMI, liver and kidney diseases, poorly controlled Diabetes Mellitus and pregnant patients were excluded from the study.

All the patiens were subjected to a thorough physical examination and investigations like $\mathrm{Hb}$, TLC, DLC, ESR, urine analysis, blood urea \& sugar, serum uric acid, lipids and electrolytes along with X-Ray chest and EKG. Other invesigations like echocardiography, $\mathrm{CT}$ scan brain and serum MDA leves ${ }^{8}$ were also studied in all cases soon after admission.

Neurological status of each patient was assessed using a modified National Institute of Health Stroke (MNIHS) Scale ${ }^{9}$ at admission and after 3 weeks and was correlated with MDA levels.

\section{RESULTS}

Mean age of stroke patients was $53.08 \pm 15.01$ years and $32 \%$ patients were below the age of 45 years. Male-female ratio was 3:2. Onset of stroke was sudden in $24 \%$, acute in $56 \%$ and progressive in $20 \%$ of patients. $80 \%$ of the patients reached the hospital within 24 hours of the onset of stroke. $96 \%$ patients presented with carotid territory and $4 \%$ with a basilar territory stroke. In the stroke group $24 \%$ of patients were hypertensive, $16 \%$ were suffering from COPD, $48 \%$ were smokers, $36 \%$ had dyslipoproteinemia, $12 \%$ were chronic alcohol drinkers and one case $(4 \%)$ was of well controlled NIDDM. None of the patients was suffering from any active coronary artery disease.

The severity of stroke as assessed by MNIHS scale at presentation revealed that $44 \%$ patients were cases of mild stroke, $24 \%$ of moderately severe stroke and $32 \%$ were suffering from very severe type of stroke. All the patients received need based therapy, but steroids were not used. $32 \%$ of patients died, $40 \%$ were left with residual deficit and only $28 \%$ recovered completely.
$88 \%$ of patients were seen to be suffering from lobar infarct and only $12 \%$ had deep seated infarcts.

Mean serum MDA levels were $1.73 \pm 0.43 \mu \mathrm{mol} / \mathrm{L}$ in control group and it was $3.33 \pm 0.75 \mu \mathrm{mol} / \mathrm{L}$ in the stroke group. The difference was highly significant $(<0.001)$. Serum MDA levels were significantly higher in those cases who were admitted to the hospital within $6 \mathrm{hrs}$ compared to those who were admitted after $24 \mathrm{hrs}$ of onset of stroke $(3.45 \pm 0.8$ vs $3.04 \pm 0.9)$. MDA levels were raised in all cases of stroke irrespective of presentation of stroke. The levels were also similarly high in all the groups, irrespective of severity of stroke. No statistically significant difference in serum MDA levels was observed in stroke patients who recovered completely, partialy or died.

\section{DISCUSSION}

Free oxygen radicals are formed during normal cellular metabolism. Cell injury associated with free radical occurs either in situation in which the scavenging system is overwhelmed or in disease states in which the protective antioxidant system is impaired. Goto ${ }^{10}$ suggested three possible mechanisms by which lipid peroxide could cause vascular damage. High serum lipid peroxide may inhibit endothelial prostacycline production, may directly injure endothelial cells or may increase platelet aggregation. Dzhandzhgava and Shakarishivili ${ }^{11}$ studies activity of antioxidant protective enzymes and found decreased levels corresponding significantly to severity of impairment and were of the opinion that these patterns can be used for diagnostic and prognostic purposes. Skochii et $\mathrm{al}^{12}$ and Yamasaki and Kogure ${ }^{13}$ studies lipid peroxidation in patients of ischemic stroke and concluded that lipid peroxide levels may be used for evaluation of treatment efficacy and prognosis of the disease.

Kibata et $\mathrm{al}^{6}$ found raised serum lipid peroxide levels in patients with recent onset stroke and the values did show a fall when the levels were estimated a few days later. Santos et $\mathrm{al}^{14}$ estimated plasma malonyl dialdehyde like material (MDA-LM) in 57 stroke patients and detected values above $50 \mathrm{~mol} / \mathrm{L}$ in $30 \%$ of patients suffering from SAH, in $68 \%$ of patients of cerebral thrombosis and in only $17 \%$ of patients with TIA. The plasma MDA- LM level and the cerebral damage did not show any correlation, as determined by CT scan. Similar findings were reported by Huang et $\mathrm{al}^{15}$ who did not find any difference in the levels between those having small or a large cerebral lesion. 

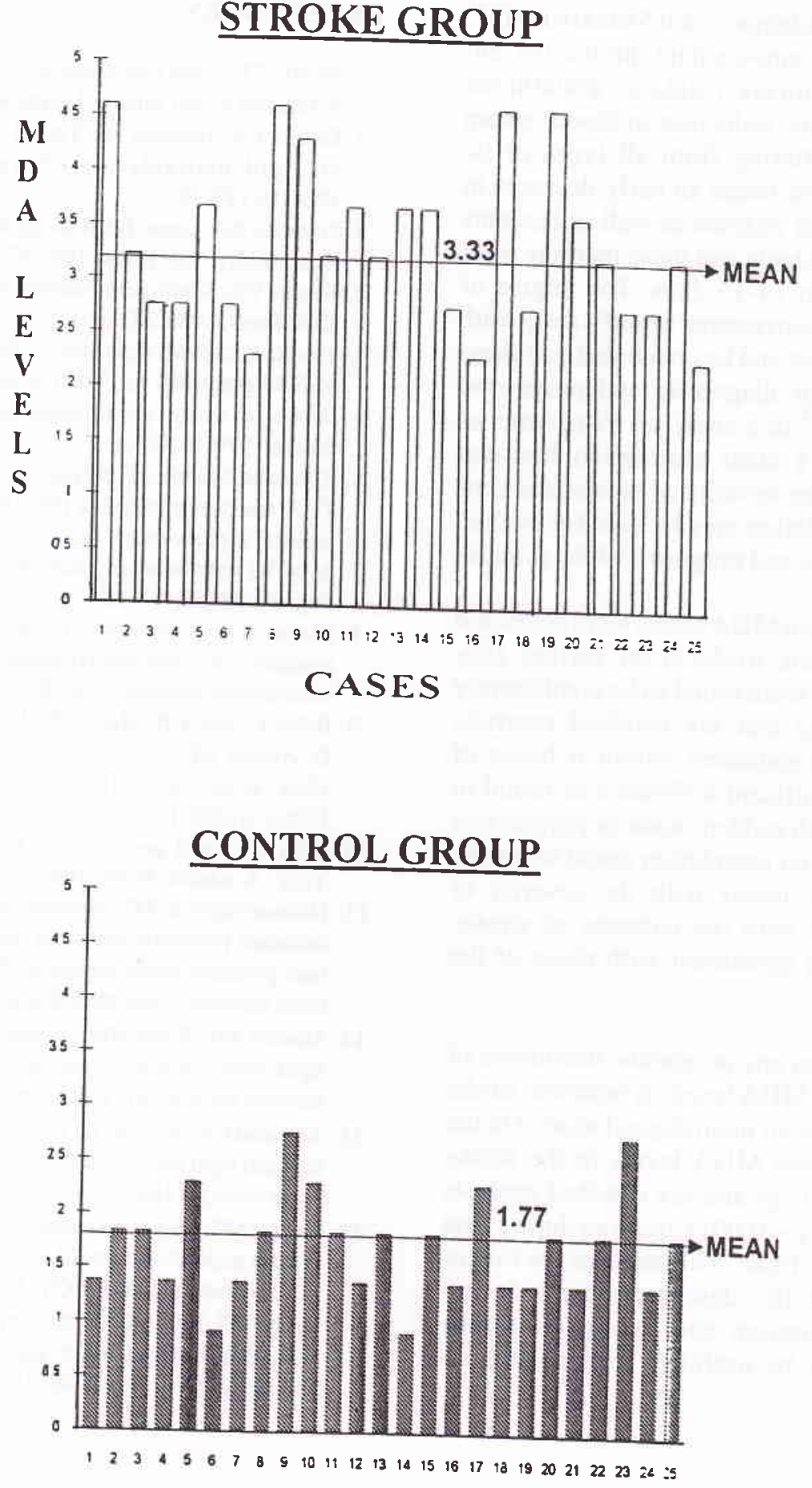

CASES

Figure 1. Serum MD levels in the stroke and control groups 
On the other hand, Dzhandzhgava and Shakarishivili ${ }^{11}$ studied the activity of anti-oxidant protective enzymes-superoxide dismutase catalase, glutathione peroxidase and glutathione reductase in blood, serum and CSF in patients suffering from all types of ischemic insult to brain and found an early decrease in the activity of antioxidant enzyme as well as contents of lipid peroxidation products and these patterns were seen to normalise within 14-15 days. The degree of alteration was found to correspond significantly with the severity of impairment and he concluded that these patterns can be used for diagnostic and prognostic purposes. Skochii et al ${ }^{12}$ in a study on 89 patients of cerebral stroke found a clear correlation between serum lipid levels and the severity of stroke and concluded that lipid peroxidation may be used for evaluation of treatment efficacy and prognosis of the disease.

In the present study, serum MDA levels were estimated in 25 patients of ischemic stroke at the earliest after hospitalisation and they were found to be significantly higher compared to age and sex matched controls, specially in patients hospitalised within 6 hours of onset of stroke. No significant difference as found in the levels in patients with sudden, acute or progressive onset stroke. Similarly no correlation could be established of serum MDA levels with the severity of neurological deficit, or with the outcome of stroke. These findings were in agreement with those of the other workers. $6,14,15$

Thus we could not detect any prognostic usefulness of determination of serum MDA levels in ischemic stroke patients as assessed by their neurological score. On the other hand, rise in serum MDA levels in the stroke patients as compared to age and sex matched controls was highly significant $(p<0.001)$, more so during first 6 hours of the onset of stroke. This stresses the role of lipid peroxidation in the damage caused during cerebral ischemic infarction and implies that antioxidant measures may be useful in limiting this ischemic injury.

\section{REFERENCES}

1. Shatter TF. Lipid peroxidation and intracellular messengers in relation to cell injury. Agents Actions 1987;22:334-40.

2. Dillard CA, Downey JE, Tappel AL. Effect of antioxidants on lipid peroxidation of iron loaded rats. Lipids 1984;19:127-33.

3. Freeman BA, Crapo JD. Biology of disease: free radicals and tissue injury. Lab Invest 1982;47:412-26.

4. Kagan VE. Lipid peroxidation in biomembranes. Florida: CRC Press, 1988:273-310.

5. Tomita I, Sano M, Serizawa S, Ohta K, Katou M. Fluctuation of lipid peroxides and relative enzyme activities at time of stroke in stroke prone spontaneously hypertensive rats. Stroke 1979;10:323-6.

6. Kibata M, Shimizu Y, Miyake K, et al. Alpha tocopherol and TBA reactive substances (TBARS) in serum of the stroke patients at acute stage. Igaku no Ayumi 1977;101:591-2.

7. A WHO collaborative study on stroke. Bull World Health Organ 1980;58:113-30.

8. Placer ZA, Cushman LL, Johnson BC. Estimation of products of lipid peroxidation (Malonyl dialdehyde) in biochemical systems. Anal Biochem 1966;16:359-64.

9. Biller J, Love BB, Marsh EE, Jones MP, Knepper LE, Jiang D, Adams HP Jr., Gordon DL. Spontaneous improvement after acute ischemic stroke: A pilot study. Stroke 1990;21:1008-12.

10. Goto U. Lipid peroxides in biology and medicine. New York: Academic Press, 1982:295-303.

11. Dzhandzhgava TG, Shakarishivili RR. Activity of an tioxidant protective enzymes and control of lipid peroxidation products blood serum CSF in patients with ischemic brain damage. Vopr Med Khim 1992;38:33-5.

12. Skochii PH, Karol HM, Tymochko MF. Characteristics of lipid peroxidation in patients with an acute disorder of cerebral circulation. Vrach Delo 1992;6:94-6.

13. Yamasaki Y, Kogure K. Possible contribution of free radicals and lipid peroxidation on pathogenesis of post ischemic brain damage. Hum Cell 1992;5:341-4.

14. Santos MT, Valles J, Aznar J, Vilches J. Determination of plasma malondialdhyde like material and its clinical application in stroke patients. J Clin Patho 1980;33:973-6.

15. Huang ZS, Lu FJ, Lee TK. Correlation between serum lipid peroxides and the lesion size in cerebrovascular disease. Clinica Chimica Acta 1992;173:325-30. 